\title{
A Case of Recurrent Dissociative Episodes in a Patient with Congenital Defects
}

\author{
Mark Miller, MD \\ Thomas Jefferson University
}

Follow this and additional works at: https://jdc.jefferson.edu/jeffjpsychiatry

Part of the Psychiatry Commons

Let us know how access to this document benefits you

\section{Recommended Citation}

Miller, MD, Mark (1983) "A Case of Recurrent Dissociative Episodes in a Patient with Congenital Defects," Jefferson Journal of Psychiatry. Vol. 1 : Iss. 1 , Article 5.

DOI: https://doi.org/10.29046/JJP.001.1.004

Available at: https://jdc.jefferson.edu/jeffjpsychiatry/vol1/iss1/5

This Article is brought to you for free and open access by the Jefferson Digital Commons. The Jefferson Digital Commons is a service of Thomas Jefferson University's Center for Teaching and Learning (CTL). The Commons is a showcase for Jefferson books and journals, peer-reviewed scholarly publications, unique historical collections from the University archives, and teaching tools. The Jefferson Digital Commons allows researchers and interested readers anywhere in the world to learn about and keep up to date with Jefferson scholarship. This article has been accepted for inclusion in Jefferson Journal of Psychiatry by an authorized administrator of the Jefferson Digital Commons. For more information, please contact: JeffersonDigitalCommons@jefferson.edu. 
Mark Miller, M.D.

\section{Case Report}

Marie, a 30 year old American-born Hispanic female, was first seen in the emergency room with suicidal ideation (the impulse to jump in front of an oncoming car), depression, anxiety, and distress about "always getting attacked so much."

Further history, mainly from her husband, disclosed a repetitive pattern of dissociative states, occurring at least monthly during their eight year marriage. Marie typically arose during the night and wandered the streets, or took "trips" lasting from several days to six weeks and covering distances from a few to a thousand miles. These episodes often culminated with a call from a hospital to the husband, stating that his wife had been found wandering in a dazed state, often dehydrated, and with evidence of physical assault. The husband reported that he knew she had been raped on at least two occasions. The episodes always had an abrupt onset, sometimes following a disagreement with the husband, and characterized by an "argumentative mood," a hostile voice, and often the throwing of household objects. The husband described a "glazed look," when Marie walked by as if she did not recognize him.

Early in their marriage, the husband often followed the patient to local bars where he found her with strange men. At times, the husband attempted to convince her to return home, only to be met with hostile responses and denial of their previous acquaintance. The patient's recollection of these trips is at best scanty. Her responses include: "I can't remember." "Sometimes I don't remember anything." "My husband tells me I do these things-maybe I do--I don't know." She describes no clear precipitant. "I just get the urge that I have to walk. I was hoping you could explain it to me."

Marie reports an occasional associated mild frontal headache, but denies any preceding odd smells, hallucinations, or alcohol or drug use. There is no history of head trauma, epilepsy, or relationship to the menstrual cycle, nor dizziness or accompanying physical discomfort.

Prior to returning from a "trip," Marie often calls her husband to say that she is cold or hungry, and that she feels hopeless and is considering suicide. She has made several attempts at cutting her wrists, the most recent two months prior to admission. When pressed for an explanation of these events, she stated, "I think there is someone else inside of me, a 'bad' Marie."

Dr. Miller is a second year psychiatry resident. 
Mental status revealed a slightly overweight, attractive Hispanic female with many scars on her arms. She sat with hands clasped between her legs, and head hung forward. Marie spoke in a soft, girlish manner, complaining of anxiety and requesting immediate answers for her problems. She resisted probing of her younger life saying that she couldn't remember, didn't know, or that it wasn't pertinent to her present problems. What memories were conveyed were devoid of associated affect. Her speech was unremarkable and there was no evidence of formal thought disorder. Marie admitted to a chronically depressed mood that had worsened over the past two months, without crying spells or vegetative symptoms. Her verbal and cognitive skills were consistent with her high school education.

Personal history revealed that she was born with an imperforate anus. A later diagnosis of Hirschprung's disease necessitated a colostomy at age three, and fourteen subsequent abdominal surgeries from infancy to age seventeen for recurrent recto-vaginal fistulas, colostomy revisions, subtotal colectomy, bowel obstruction, and pelvic abscess. This medical information was obtained from her hospital record, as Marie showed a poor understanding of her illnesses and altered anatomy, stating: "I only know I had something wrong and I needed a colostomy."

Marie is the third eldest of eleven children, the younger six of whom were fathered by multiple men. She was raised in a major city, and was placed in a girls' home by child welfare at age fifteen when her mother decided she "would be better off there." Marie's early memories are filled with references to feelings of pain, degradation, uncertainty, and freakishness. She recalls hiding her colostomy at school, feeling sexually defective, and being told that she was sterile.

With the aid of tutors and a supportive school, Marie graduated from high school with above average grades. She married shortly thereafter, and moved to another city where she worked as a pediatric nurse's aid for six years. She divorced her first husband for his infidelity after three years, subsequently left work and obtained welfare. She married her present husband two years later. Her husband describes Marie as sweet, loving, and a meticulous housekeeper. He feels affection for "that Marie," but has become increasingly intolerant of her baffling "trips" over the years. He now sees her as dependent, demanding, and unjustifiably jealous. He also feels that his increasing alcohol consumption is his way of escaping from her.

Marie reports her first sexual intercourse at age seventeen, although her memories are rathered fragmented. She denies specific sexual symptoms, but says of sex: "I can take it or leave it; I only have sex for my husband."

Brain CT Scan, EEG with nasopharynegeal leads, and medical evaluation vere all unremarkable.

Marie began her hospital course with a guarded and isolated manner. She claimed to enjoy group therapy, since she rarely interacted with people other than her husband. A visit from the ostomy therapist (also possessing a colostomy) brought a flood of tears and statements such as: "No one ever explained it to me that way." "I never knew anyone with colostomy." "She has a colostomy, but she's so pretty." 
There were no dissociative states observed in the hospital although once, on the evening prior to being presented as a case conference, she had the impulse to "walk" off the ward. In another instance, her faithfully visiting husband, who often arrived with alcohol on his breath, called to say that he could not come that day. Marie concluded that he was drunk. She became irate, threw an ashtray across the room, and became agitated enough to require sedation and temporary seclusion.

With supportive therapy involving the husband, ostomy education, and low dose benzodizapines for anxiety, Marie improved in her grooming, socialization, and subjective comfort. She was discharged after sixteen days with planned weekly follow-up.

\section{Discussion}

of the many facets of this complicated case, Marie's early childhood surgical traumas clearly are paramount. This woman never had a normal body image. Her childhood and adolescence were marked by frequent, lengthy hospitalizations for her bowel disease and its complications. This severely limited normal schooling, peer relationships and family relationships. No family was available to interview, but hospital records describe a distant, uninvolved mother who never visited Marie in later hospitalizations and who stated she would be better off placed in a group home. Father visited periodically and is recalled favorably. Marie has not had any contact with her mother or siblings for the past eight years, nor with her father for three years, explaining unconvincingly that she lost their addresses.

Studies of children with physical disfigurement from surgery have shown that attempted inattention to deformities can result in a poorly integrated image of the body and the self. The child's devaluation of the diseased part extends to his whole person, and generally reflects the view of family members. The absence or withdrawal of parental support during the worst periods of Marie's illness is highly significant. Surgically traumatized children also of ten express aggressive fantasies in play therapy, with defenses against intense rage anxiety. Marie's bland lack of interest in finding her mother may represent a defense against rage toward the mother.

Marie's ego functioning is quite primitive, as evidenced by her massive use of denial of the extent of her illness and altered anatomy, as well as her low self image, perceived helplessnes, and dependence on her husband for total emotional sustenance: "He's my father, mother, husband, and only friend."

Dissociative states often are a final, desperate defense against intolerable impulses, particularly sexual and aggressive ones, that threaten to enter consciousness. Marie is probably enraged at those whom she identifies with her childhood suffering, particularly her parents who abandoned her. She apparently displaces some of this anger onto her husband, the current representative of her important early life figures. Marie denies the importance of sexuality, but clearly has major conflicts regarding her deformed body, infertility, and altered and diseased sexual organs ("All I remember is that I had pus draining from my vagina.") During her wanderings, Marie of ten seemed to be searching for missing love objects in her frequent relations 
with strange men. Perhaps she was unconsciously striving to prove her worthiness in spite of her deformities. Or, in light of the frequent physical and sexual assaults experienced during her "trips," perhaps she has an unconscious wish to be bruised, cut, or denigrated in a way similar to her "injuries" under the scalpel. Marie's surgical mutilations may have become psychologically linked with the consistent care and attention during multiple hospitalizations.

Therapy with this patient will be quite difficult, in light of her early childhood trauma and deprivation. Her propensity for dissociation, when experiencing anxiety, will interfere with the use of exploratory techniques. My current approach is chiefly aimed at support and ego strengthening. 
1. Brown SL: Dissociation of pleasure in psychopathology. J Nerv Ment Dis $169: 3-17,1981$.

2. Christenson $R$, et al: Reactivation of traumatic conflicts, Am J Psychiatry $138: 984-985,1981$.

3. Freud S: Studies on hysteria. The Complete Works--Standard Edition, London, The Hogarth Press, 1921.

4. Krystal H: Trauma and affects. Psychoanalytic Study of the Child 33:81117, 1978.

5. Ludwig AM, et al: The objective study of a multiple personality. Arch Gen Psychiatry 26:298-310, 1972.

6. Marmer SS: Psychoanalysis of multiple personality. Int J Psychoanal $61: 439-459,1980$.

7. Schenk L, Bear D: Multiple personality and related dissociative phenomena in patients with temporal lobe epilepsy. Am J Psychiatry 138:1311-1316, 1981 .

8. Watson EJ, Johnson AM: The emotional significance of acquired physical disfigurement in children. Am J orthopsychiatry 28:85-97, 1958. 